Archive for

Organic Chemistry
Arkivoc 2018, part iii, 0-0

to be inserted by editorial office

\title{
The synthesis of 2,3-dihydroquinazoline-4(1H)-one and dihydroisoindolo[2,1- a]quinazoline-5,11-dione derivatives in the presence of imidazolium ionic liquid sulfonic acid functionalized SBA-15: a novel feature of SBA-15
}

\author{
Sepideh Abbasian ${ }^{\mathrm{a}}$, Hassan Kabirifard*a and Mohammad Mahdavi ${ }^{\mathrm{b}}$ \\ ${ }^{a}$ Department of Chemistry, North Tehran Branch, Islamic Azad University, Tehran, Iran \\ ${ }^{b}$ Endocrinology \& Metabolism Research Institute, Tehran University of Medical, Iran \\ Email: $\underline{h \text { kabirifard@iau-tnb.ac.ir }}$
}

\begin{abstract}
Imidazole-based ionic liquid-supported on SBA-15 (ImIL-Sul-SBA-15) as a novel heterogeneous catalyst was designed, synthesized and characterized by FT-IR, scanning electron microscopy (SEM), transmission electron microscopy (TEM), and Brunauer-Emmett-Teller (BET) analysis. This novel nano structure was used for the synthesis of various 2,3-dihydroquinazoline-4(1H)-one and dihydroisoindolo[2,1-a]quinazoline-5,11-dione derivatives via three-component reaction between isatoic anhydride, amines and aromatic aldehydes at $50{ }^{\circ} \mathrm{C}$ in ethanol and water mixture as solvent. We found the synthetic imidazolium ionic liquid sulfonic acid functionalized SBA-15 as a convenient catalyst for this methodology. The catalyst performs the reaction in mild reaction conditions, and can easily be separated from the reaction mixture by simple filtration, with no need to tedious purification steps.
\end{abstract}

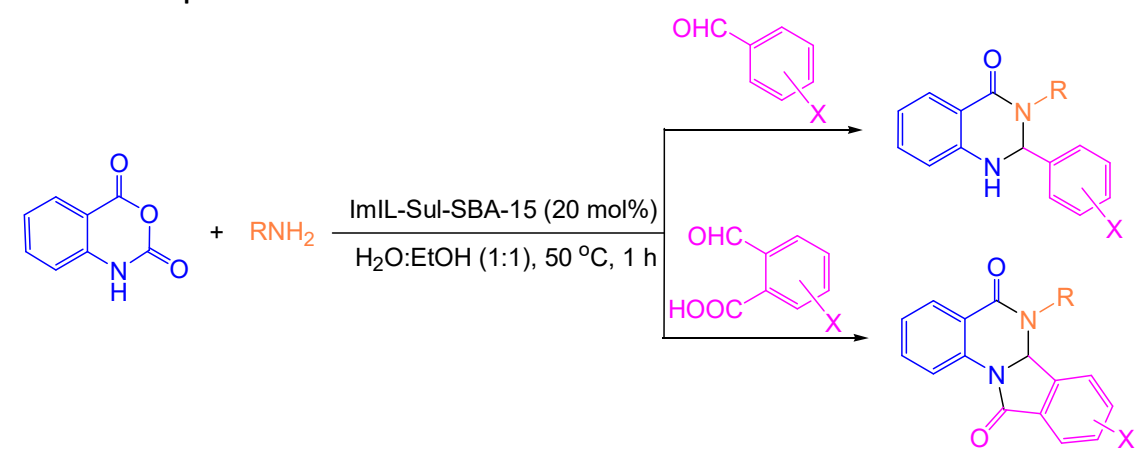

Keywords: Isatoic anhydride, Imidazolium ionic liquid sulfonic acid functionalized SBA-15, Three-component reaction, 2,3-Dihydroquinazolin-4(1H)-one, Dihydroisoindolo[2,1-a]quinazoline-5,11-dione 


\section{Introduction}

The catalysts are notable moiety of very synthetic reactions due to their properties such as decreasing of reaction time and temperature. In addition, the catalytic processes are ecologically sustainable because the catalysts prevent in environmental pollution. In the last decade, several developments were proceeded to design, synthesis and application examination of catalysts for various chemical and pharmaceutical synthetic processes. The heterogeneous catalysts easily separate and recover from reaction mixture. However, these catalysts must have many active sites, good selectivity, recyclability, reusability, and high stability. The efficiency of solid catalysts is increased by great pores with numerous active sites. ${ }^{1-3}$

Mesoporous silica nanoparticles are important due to their porous structure and high surface area. These materials have been used as support for catalysts because of their unique properties. ${ }^{4-6}$

2,3-Dihydroquinazolin-4(1H)-ones (DHQZs) are important classes of heterocycles and have the broad range of pharmacological and biological properties. These compounds exhibit antiviral, ${ }^{7}$ anti-inflamatory, ${ }^{8,9}$ antihistamine $^{10}$ cytotoxic, $^{11}$ antibiotic, $^{12}$ analgesic, ${ }^{13}$ anticonvulsant, ${ }^{13}$ antitumor, ${ }^{11,13}$ vasodilatory, ${ }^{14}$ antidefibrillatory, ${ }^{15}$ antihypertensive activities. ${ }^{16}$

According to these wide ranges of pharmacological activities, several synthetic routes have been reported for the preparation of DHQZs. The important method for the synthesis of DHQZs involves the condensation of anthranilamide with aldehydes or ketones using several catalysts such as montmorillonite $\mathrm{K}-10,{ }^{17}$ gallium(III) triflate, $^{18}$ 1-butyl-3-methylimidazolium tetrafluoroborate $\left.([\mathrm{bmim}] \mathrm{BF})_{4}\right)^{19} \mathrm{MCM}-41-\mathrm{SO}_{3} \mathrm{H}_{,}{ }^{20} \quad \mathrm{Al}^{19} / \mathrm{Al}_{2} \mathrm{O}_{3}$

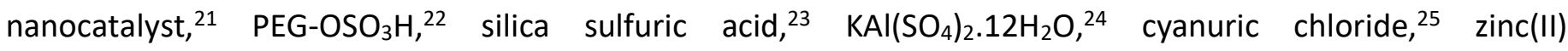
perfluorooctanoate $\left[\mathrm{Zn}(\mathrm{PFO})_{2}\right],{ }^{26}$ and molecular iodine. ${ }^{27}$ In addition, the use of three-component reaction between isatoic anhydride, amines and aromatic aldehydes catalyzed by Lewis and Brønsted acid catalysts, is an applicable route for the synthesis of DHQZs. ${ }^{28,29}$ However, most of these methods proceeded by the use of complex and expensive catalysts or media, and have notable disadvantages such as harsh reaction conditions, long reaction times, and low yields. Therefore, the development of a novel and efficient approach to produce DHQZs using efficient catalysts is still desirable. Regarding the advantages of mesoporous silica nanoparticles, in this paper we repost a catalyst based on functionalized SBA-15 by imidazolium ionic liquid sulfonic acid for the synthesis of 2,3-dihydroquinazoline-4(1H)-ones (4a-d) and dihydroisoindolo[2,1-a]quinazoline-5,11-diones (6a-j) (Scheme 1).

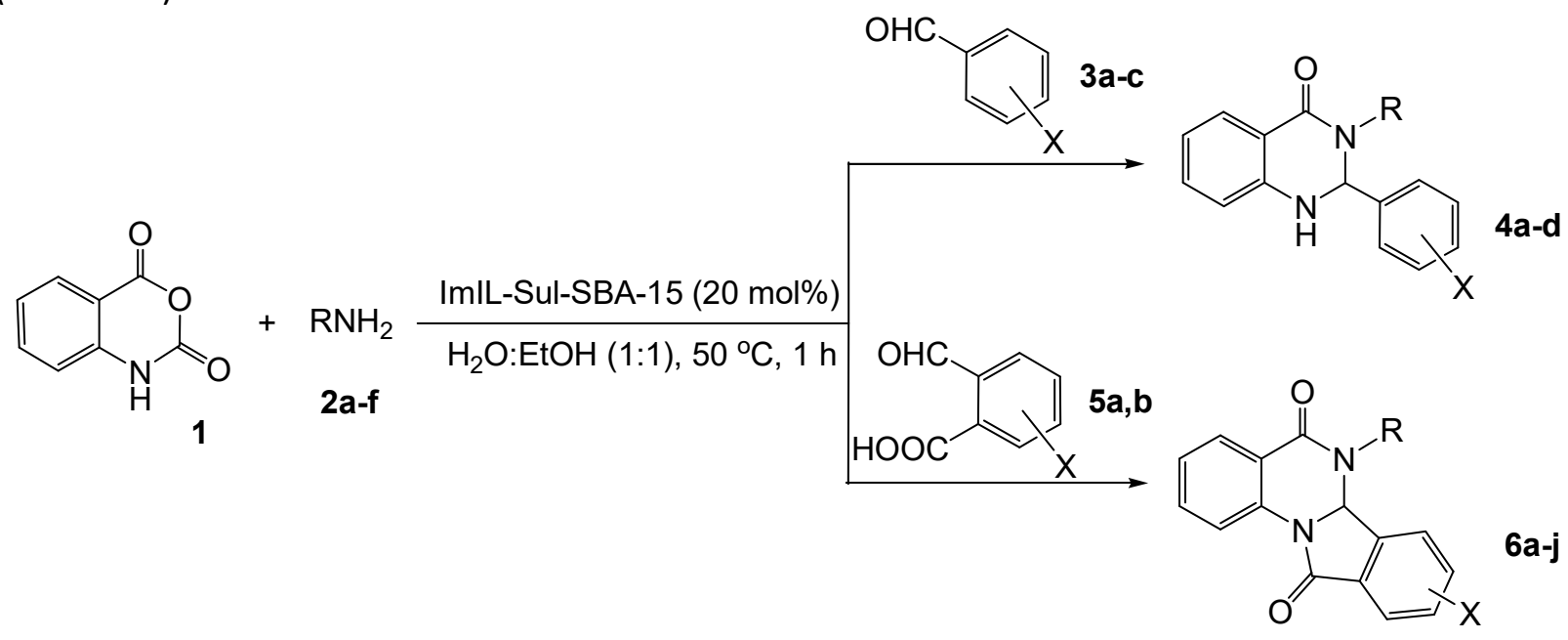

Scheme 1. The synthesis of 2,3-dihydroquinazoline-4(1H)-ones (4) and dihydroisoindolo[2,1-a]quinazoline5,11-diones (6) in the presence of ImIL-Sul-SBA-15. 


\section{Results and Discussion}

The catalyst was prepared by the synthesis and functionalization of SBA-15 mesoporous silica nanoparticles. SBA-15 mesoporous silica was prepared via solvothermal reaction of tetraethyl orthosilicate in acidic conditions. After the preparation of SBA-15 mesoporous silica, the nanoparticles were functionalized by sulfonic acid, and finally were treated by methyl imidazole. The preparation steps of the catalyst can be seen in Scheme 2.

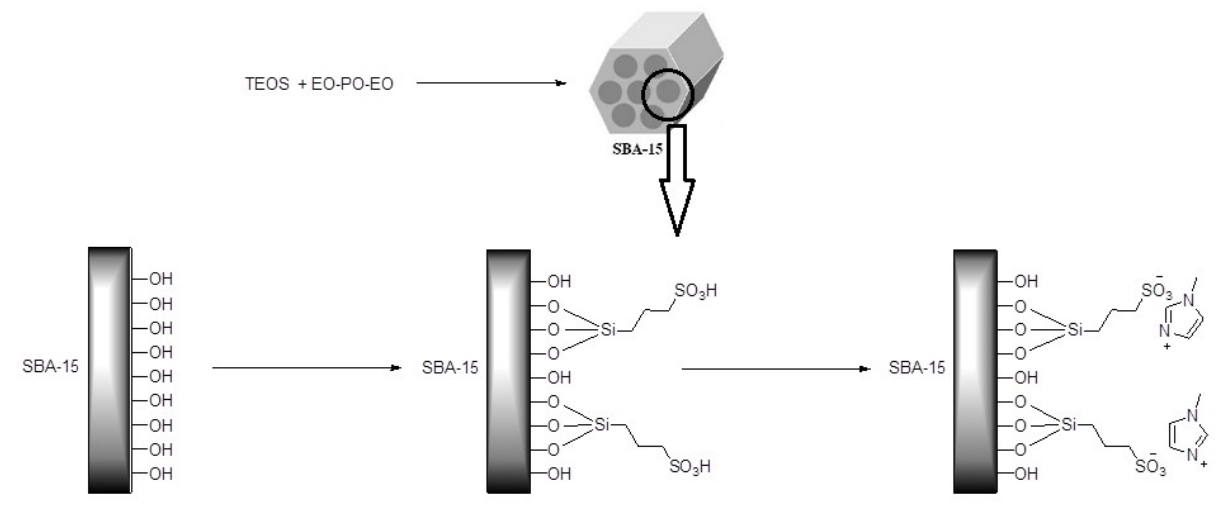

Scheme 2. The preparation steps of the catalyst.

FT-IR spectroscopy was used for the determination of the functionalities of the catalyst (Figure 1). A sharp absorbance at $1100 \mathrm{~cm}^{-1}$ can be correlated to the Si-O vibration bands. A broad peak at $3340 \mathrm{~cm}^{-1}$ can be correlated to hydroxyl groups of the catalyst. $\mathrm{S}=\mathrm{O}$ vibrations can be observed as a vibration band at $1190 \mathrm{~cm}^{-1}$. Imidazole vibrations can be seen at $1447 \mathrm{~cm}^{-1}$.

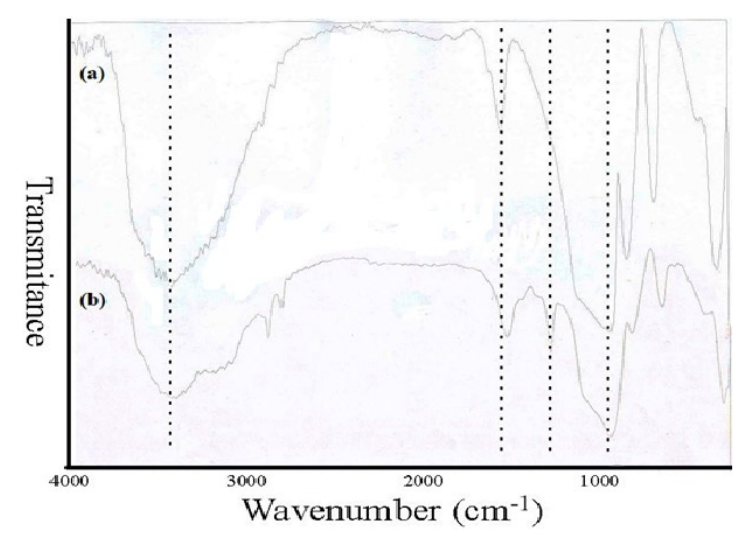

Figure 1. FT-IR spectra of alkyl-sulfonic supported acid SBA-15 (a) and ionic liquid supported SBA-15 (b).

The catalyst was characterized by various methods. TEM and SEM microscopy were applied for determining the microstructure, particle size and morphology of the catalyst. The images for TEM and SEM can be seen in Figure 2 respectively. The ordered porous structure of ImIL-Sul-SBA-15 catalyst can clearly be observed in TEM images. In SEM images, the rod like morphology of ImIL-Sul-SBA-15 can be seen. 


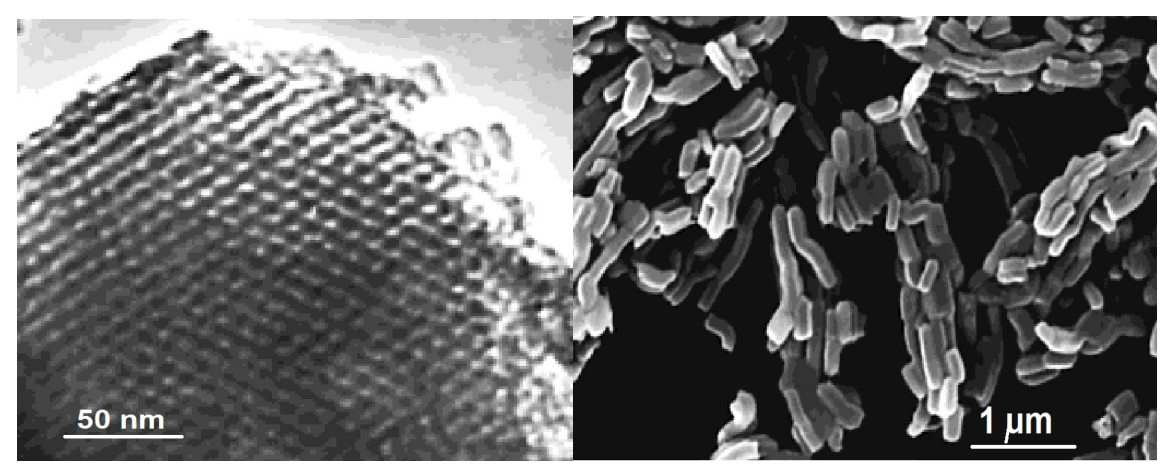

Figure 2. TEM (left) and SEM (right) images of the catalyst.

For the determination of the pore size and the size dispersity of the pores of the catalyst, nitrogen adsorption desorption method was used. The results, which are shown in Figure 3, show the pore size of the catalyst to be $85 \mathrm{~nm}$. As can be seen, the pore size distribution of the catalyst is narrow.

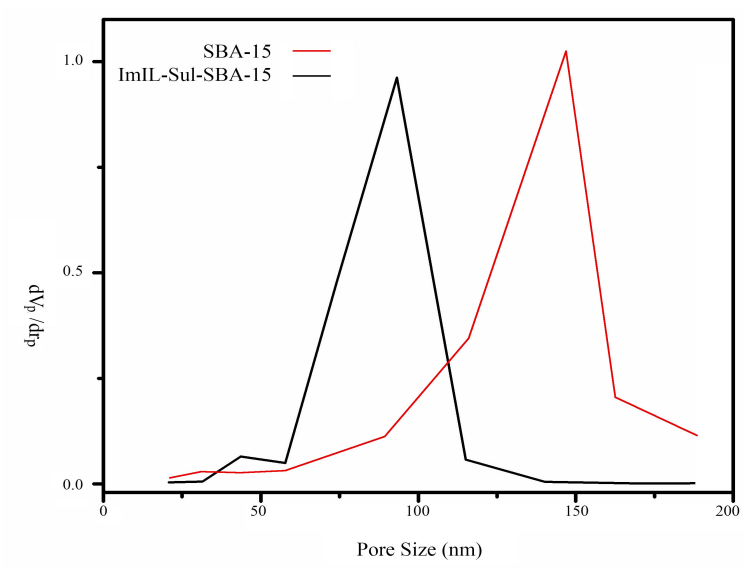

Figure 3. Pore size analysis of the catalyst.

The thermal stability of the catalyst was investigated by TGA method. The TGA results can be seen in Figure 4. A weight loss has happened in about $100^{\circ} \mathrm{C}$, which can be related to the evaporation of the water. In 230-250 ${ }^{\circ} \mathrm{C}$ a sharp weight loss can be observed, which can be correlated to the thermal decomposition of the organic functionalities. It can be observed in TGA results that, the catalyst is stable till $230{ }^{\circ} \mathrm{C}$ and no thermal decomposition has been observed in lower temperatures. A comparison between SBA-15 and ImIL-Sul-SBA-15 in Figure 4 shows about $10 \%$ of functionalization by weight.

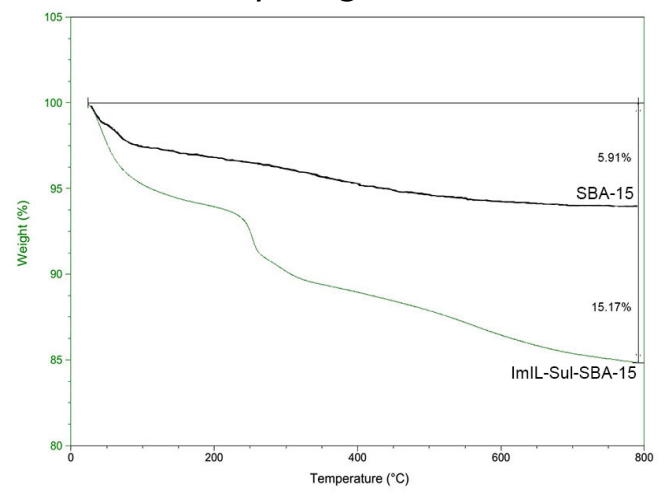

Figure 4. TGA analysis of the catalyst. 
The activity of our catalyst was examined in three-component reactions between isatoic anhydride, amines and aromatic aldehydes for the synthesis of various 2,3-dihydroquinazolin-4(1H)-one (4) and dihydroisoindolo[2,1-a]quinazoline-5,11-dione (6) derivatives. So, the reaction between isatoic anhydride 1, benzylamine $\mathbf{2 a}$ and 4-chlorobenzaldehyde $\mathbf{3 a}$, as a model reaction, was investigated in various reaction conditions.

As shown in Table 1, no product was detected when the reaction occurred at room temperature in the presence of $10 \mathrm{~mol} \%$ of the ImIL-Sul-SBA-15 in water after $10 \mathrm{~h}$ (entry 1). The DHQZ 4 was generated in low yield (33\%) by increasing of reaction temperature to $40{ }^{\circ} \mathrm{C}$ after $1 \mathrm{~h}$ (entry 2). Although, the increasing of reaction temperature to $50{ }^{\circ} \mathrm{C}$ led to increasing of the yield of product to $38 \%$ (entry 3 ), more increasing of reaction temperature did not effect on the yield of product (entry 4). Continuously, the effect of amount of ImIL-Sul-SBA-15 was tested and the desired product was generated in $67 \%$ yield in the presence of 20 mol\% of our catalyst (entry 6). Performing the reaction with higher amounts of catalyst did not lead to higher product yields (entries 7 and 8). Then, we examined the reaction in various solvents (entries 9-16), and surprisingly, it was found that the best yield of product was achieved in the mixture of $\mathrm{EtOH}: \mathrm{H}_{2} \mathrm{O}(1: 1)$ and $\mathrm{EtOH}$ although the reaction led to acceptable yields in DMF and THF (entry 12,13).

Table 1. Optimization of reaction conditions for the synthesis of DHQZ 4a in the presence of ImIL-Sul-SBA-15a

\begin{tabular}{|c|c|c|c|c|c|}
\hline & 1 & $2 a$ & $3 \mathbf{a}$ & & $4 a$ \\
\hline Entry & Amount (mol\%) & Solvent & Temp. $\left({ }^{\circ} \mathrm{C}\right)$ & Time (h) & Yield $^{b}(\%)$ \\
\hline 1 & 10 & $\mathrm{H}_{2} \mathrm{O}$ & r.t & 10 & 0 \\
\hline 2 & 10 & $\mathrm{H}_{2} \mathrm{O}$ & 40 & 1 & 33 \\
\hline 3 & 10 & $\mathrm{H}_{2} \mathrm{O}$ & 50 & 1 & 38 \\
\hline 4 & 10 & $\mathrm{H}_{2} \mathrm{O}$ & 60 & 1 & 38 \\
\hline 5 & 15 & $\mathrm{H}_{2} \mathrm{O}$ & 50 & 1 & 54 \\
\hline 6 & 20 & $\mathrm{H}_{2} \mathrm{O}$ & 50 & 1 & 67 \\
\hline 7 & 30 & $\mathrm{H}_{2} \mathrm{O}$ & 50 & 1 & 67 \\
\hline 8 & 50 & $\mathrm{H}_{2} \mathrm{O}$ & 50 & 1 & 65 \\
\hline 9 & 20 & $\mathrm{CH}_{2} \mathrm{Cl}_{2}$ & 50 & 10 & 57 \\
\hline 10 & 20 & $\mathrm{CHCl}_{3}$ & 50 & 10 & 55 \\
\hline 11 & 20 & DMSO & 50 & 10 & 60 \\
\hline 12 & 20 & DMF & 50 & 10 & 67 \\
\hline 13 & 20 & THF & 50 & 10 & 58 \\
\hline 14 & 10 & toluene & 50 & 10 & 50 \\
\hline 15 & 10 & $\mathrm{EtOH}$ & 50 & 1 & 88 \\
\hline 16 & 20 & EtOH: $\mathrm{H}_{2} \mathrm{O}(1: 1)$ & 50 & 1 & 90 \\
\hline
\end{tabular}

a Reaction conditions: use of isatoic anhydride $1(1.0 \mathrm{mmol})$, benzylamine $2 \mathrm{a}(1.0 \mathrm{mmol})$ and 4-chlorobenzaldehyde $3 a$ $(1.0 \mathrm{mmol})$ and appropriate amount of ImIL-Sul-SBA-15; solvent ( $3 \mathrm{~mL})$; related temperature; time. ${ }^{\mathrm{b}}$ Isolated yield.

To show the generality of this new method, the reactions were performed using various amines $\mathbf{2}$, and aromatic aldehydes 3 with isatoic anhydride 1 in the presence of 20 mol\% ImIL-Sul-SBA-15 in $3 \mathrm{~mL}$ of 
EtOH: $\mathrm{H}_{2} \mathrm{O}(1: 1)$ at $50{ }^{\circ} \mathrm{C}$. The reactions led to produce the corresponding DHQZs $4 a-d$ in $85-93 \%$ yields (Table 2). In addition, the reaction between isatoic anhydride 1, amines $\mathbf{2}$ and 2-carboxyaldehydes 5 was studied under similar reaction conditions and the corresponding dihydroisoindolo[2,1- $a$ ]quinazoline-5,11-diones $6 \mathbf{a}-\mathbf{j}$ was generated in $86-95 \%$ yields (Table 2). All the reactions reached to completion within $1 \mathrm{~h}$.

Table 2. ImIL-Sul-SBA-15 catalyzed synthesis of 2,3-dihydroquinazoline-4(1H)-ones (4) and dihydroisoindolo[2,1-a]quinazoline-5,11-diones (6) ${ }^{\text {a }}$

\begin{tabular}{|c|c|c|c|c|}
\hline Entry & Amine (2); R= & Aldehyde ( $\mathbf{3}$ and $\mathbf{5}) ; \mathrm{X}=$ & Product (4 and $\mathbf{6}$ ) & Yield $^{b}(\%)$ \\
\hline 1 & 2a; $\mathrm{PhCH}_{2}$ & $3 a ; 4-C l$ & $4 a$ & 90 \\
\hline 2 & 2a; $\mathrm{PhCH}_{2}$ & $3 b ; 4-\mathrm{CH}_{3} \mathrm{O}$ & $4 b$ & 86 \\
\hline 3 & 2a; $\mathrm{PhCH}_{2}$ & $3 c ; 2,3-\mathrm{Cl}_{2}$ & $4 c$ & 85 \\
\hline 4 & 2b; $\mathrm{CH}_{2}=\mathrm{CHCH}_{2}$ & $3 a ; 4-C l$ & $4 d$ & 93 \\
\hline 5 & 2a; $\mathrm{PhCH}_{2}$ & 5a; H & $6 a$ & 90 \\
\hline 6 & 2b; $\mathrm{CH}_{2}=\mathrm{CHCH}_{2}$ & 5a; H & $6 b$ & 95 \\
\hline 7 & 2c; $2-\mathrm{ClC}_{6} \mathrm{H}_{4} \mathrm{CH}_{2}$ & $5 a ; H$ & $6 c$ & 88 \\
\hline 8 & 2d; $2-\mathrm{C}_{4} \mathrm{H}_{3} \mathrm{OCH}_{2}$ & $5 a ; H$ & $6 d$ & 88 \\
\hline 9 & $2 \mathrm{e} ; 2-\mathrm{C}_{5} \mathrm{H}_{4} \mathrm{NCH}_{2}$ & $5 a ; H$ & $6 e$ & 91 \\
\hline 10 & 2f; $4-\mathrm{ClC}_{6} \mathrm{H}_{4} \mathrm{CH}_{2}$ & $5 a ; H$ & $6 f$ & 87 \\
\hline 11 & 2a; $\mathrm{PhCH}_{2}$ & $5 b ; 2,3-\left(\mathrm{CH}_{3} \mathrm{O}\right)_{2}$ & $6 g$ & 89 \\
\hline 12 & 2d; $2-\mathrm{C}_{4} \mathrm{H}_{3} \mathrm{OCH}_{2}$ & $5 \mathbf{b} ; 2,3-\left(\mathrm{CH}_{3} \mathrm{O}\right)_{2}$ & $6 \mathrm{~h}$ & 87 \\
\hline 13 & $2 \mathrm{e} ; 2-\mathrm{C}_{5} \mathrm{H}_{4} \mathrm{NCH}_{2}$ & $5 \mathrm{~b} ; 2,3-\left(\mathrm{CH}_{3} \mathrm{O}\right)_{2}$ & $6 i$ & 90 \\
\hline 14 & 2f; $4-\mathrm{ClC}_{6} \mathrm{H}_{4} \mathrm{CH}_{2}$ & $5 b ; 2,3-\left(\mathrm{CH}_{3} \mathrm{O}\right)_{2}$ & $6 \mathbf{j}$ & 86 \\
\hline
\end{tabular}

${ }^{a}$ All the reactions were carried out using isatoic anhydride $\mathbf{1}(1.0 \mathrm{mmol})$, amine $\mathbf{2}(1.0 \mathrm{mmol})$, aromatic aldehyde $\mathbf{3}$ or 5 $(1.0 \mathrm{mmol})$, and ImIL-Sul-SBA-15 (w/w 20\%) in EtOH: $\mathrm{H}_{2} \mathrm{O}(3 \mathrm{~mL})$ at $50{ }^{\circ} \mathrm{C} .{ }^{b}$ Isolated yield.

The structures of the products 4 and 6 were deduced by $I R,{ }^{1} H N M R,{ }^{13} C N M R$ and some Mass spectroscopy. All spectroscopic studies are available in supporting information.

We suggest that ImIL-Sul-SBA-15 catalyzes the reaction as a mild Lewis acid. A plausible mechanism for the formation of isoindolo[2,1-a]quinazoline-5,11-dione derivatives (6) is depicted in Scheme 3. The nucleophilic attack of amine (2) on the activated carbonyl carbon by ImIL-Sul-SBA-15 of isatoic anhydride (1) obtains 2aminobenzamide intermediate. The further nucleophilic attack by the amino group of 2-aminobenzamide on the carbonyl carbon of 2-formylbenzoic (5) facilitated by ImIL-Sul-SBA-15 generates the Schiff base. Then, the 
intramolecular acylamino group attacks the ImIL-Sul-SBA-15-activated Schiff base to form the quinazoline; finally, an intramolecular dehydration to give the desired product 6.

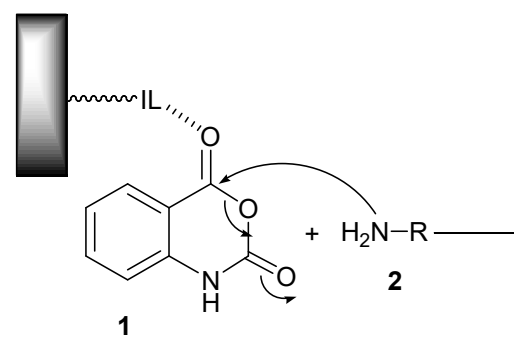<smiles>[R]NC(=O)c1ccccc1NC(=O)O</smiles>

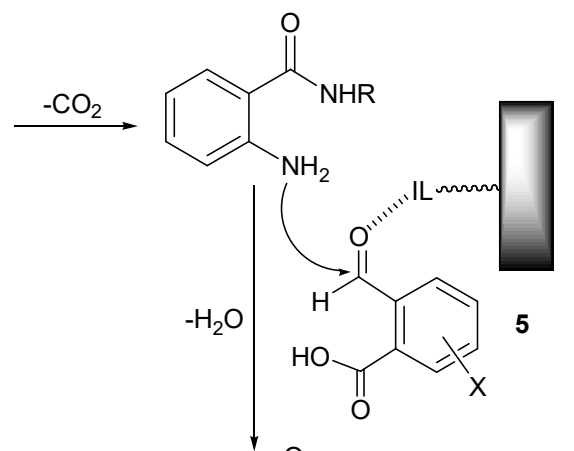

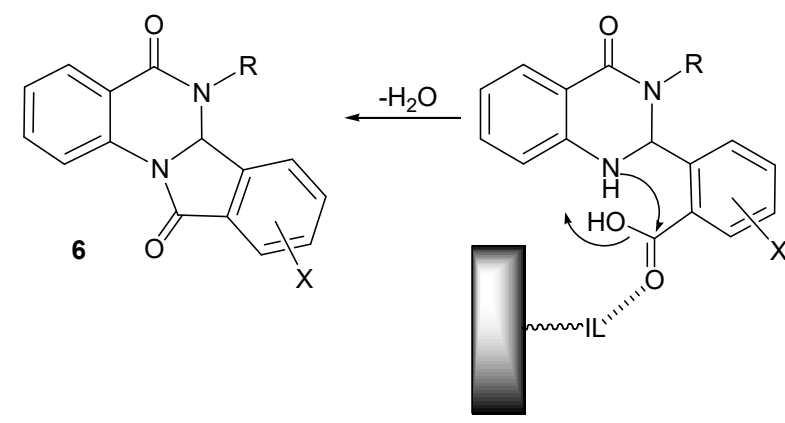<smiles>[X]c1ccccc1C(=O)N(CC)c1ccccc1C(=O)NCCCCC</smiles>

Scheme 3. Plausible mechanism for the formation of isoindolo[2,1-a]quinazoline-5,11-diones (6).

After completion of the reaction, the precipitate was separated by filtration. The resulting precipitate is mixture of desired product and ImIL-Sul-SBA-15. To separate the products from the catalyst, this solid was washed with EtOH and ImIL-Sul-SBA-15 was remained as solid. A great advantage of this catalyst in this synthesis is simple separability using filtration, which can easily lead to the facile reusability of the catalyst. To study the recyclability of the ImIL-Sul-SBA-15, the reused catalyst was employed for another reaction. We found that, the catalyst could be reused successfully up to 6 times without obvious loss of catalytic activity. The results are presented in Figure 5.

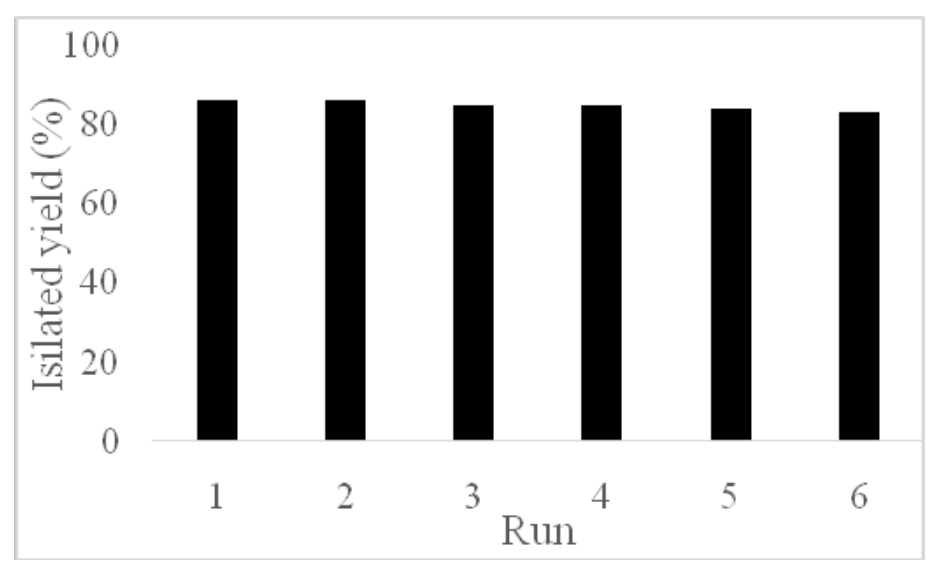

Figure 5. The recycling studies for ImIL-Sul-SBA-15. 
An advantage of this catalytic system is that, the products are obtained in milder reaction conditions. In a similar report, the products are obtained in higher temperature and acetic acid is used as solvent, which is more difficult than the current report. ${ }^{30}$ The other advantage of this catalytic method is its non-toxic feature. Metallic species such as gallium(III) triflate have been used as catalyst for the synthesis of quinazolinone derivatives. ${ }^{18}$ These species are toxic and harmful for the environment, which limits their use in industries.

\section{Conclusions}

In conclusion, we have developed an efficient catalytic approach for the synthesis of various 2,3-dihydroquinazoline4(1H)-ones (4) and dihydroisoindolo[2,1-a] quinazoline-5,11-diones (6) via reaction between isatoic anhydride 1, amines $\mathbf{2}$ and aldehydes $\mathbf{3}$ or 2-carboxyaldehydes $\mathbf{5}$ in the presence of ImIL-Sul-SBA-15. The reactions were carried out without the use of high temperature, and complex, toxic and expensive catalyst and reagents. The recoverability and reusability of our catalyst, relatively short reaction times and high yield of the products are the other advantages of our protocol. We believe that the success in this process could open the door to the design of diverse reactions and the generation of interesting organic compounds in the presence of our synthetic catalyst.

\section{Experimental Section}

General. Solvents, reagents and chemicals were obtained from Merck (Germany) and Fluka (Switzerland) Chemical Companies. Elemental analyses were performed using a Heraeus CHN-O-Rapid analyzer. The IR spectra were obtained on a Nicolet Magna FT-IR 550 spectrophotometer (potassium bromide disks). Nuclear magnetic resonance spectra were recorded on a Bruker FT-500 spectrometers at 500 and $125 \mathrm{MHz}$ instrument using tetramethylsilane (TMS) as internal standard in pure deuterated solvents. Chemical shifts are given in the $\delta$ scale in parts per million (ppm) and singlet $(\mathrm{s})$, doublet $(\mathrm{d})$, triplet $(\mathrm{t})$, multiplet $(\mathrm{m})$ and doublet of doublets (dd) are recorded. Mass spectra were recorded on an Agilent Technology (HP) mass spectrometer operating at an ionization potential of $70 \mathrm{eV}$. Thin layer chromatography was carried out on silica gel 254 analytical sheets obtained from Fluka. Transition electron microscope images were recorded on a Hitachi S4160. Thermogravimetric analysis of the samples were recorded by TGA Q50 V6.3 Build 189 instrument. SEM image was papered by Hitachi S-4160 (Cold Field Emission). BET Quantachrome ChemBET 3000 was applied for determination pore size analysis.

Synthesis of SBA-15. SBA-15 was prepared according to previously reported method. ${ }^{31}$ To a 1-L Erlenmeyer flask were added ethyleneoxide-propyleneoxide-ethyleneoxide (EO-PO-EO) triblock copolymer (18.0 g), DI water $(561 \mathrm{~g})$, and concentrated $\mathrm{HCl}(99.5 \mathrm{~g})$. This mixture was stirred overnight at room temperature to dissolve the polymer template. Tetraethyl orthosilicate TEOS ( $39.8 \mathrm{~g})$ was added to the solution and stirred for $5 \mathrm{~min}$, followed by stirring at $35^{\circ} \mathrm{C}$ for $20 \mathrm{~h}$. A static treatment for $24 \mathrm{~h}$ at $80^{\circ} \mathrm{C}$ was used to swell the pores. The mixture was decanted to remove most of the solution, and the white solid was filtered with $3 \mathrm{~L}$ of $\mathrm{DI}$ water, recovered, and dried at $60^{\circ} \mathrm{C}$ for $24 \mathrm{~h}$. The white powder was calcined to remove the polymer template using the following temperature profile: (1) heating to $200^{\circ} \mathrm{C}$ at $1.2^{\circ} \mathrm{C} / \mathrm{min}$, (2) holding at $200^{\circ} \mathrm{C}$ for $1 \mathrm{~h}$, (3) heating to $550^{\circ} \mathrm{C}$ at $1.2^{\circ} \mathrm{C} / \mathrm{min}$, (4) holding at $550^{\circ} \mathrm{C}$ for $6 \mathrm{~h}$, and (5) cooling to $200^{\circ} \mathrm{C}$ at $1.2^{\circ} \mathrm{C} / \mathrm{min}$.

Preparation of supported alkyl-sulfonic acid. This product was prepared according to modified method, reported by Ziarani et al. ${ }^{31}$ To a solution of $1 \mathrm{~g}$ of MPTMS in $10 \mathrm{~mL}$ of ethanol and $10 \mathrm{~mL}$ of water was added $250 \mathrm{mg}$ of SBA-15. The mixture was sonicated for $15 \mathrm{~min}$ and refluxed overnight. The SBA-15 supported thiols 
(SBA-15-SH) were recovered magnetically and washed three times with $20 \mathrm{~mL}$ of water. The recovered SBA$15-\mathrm{SH}$ was oxidized by reaction with $10 \mathrm{~mL}$ of $30 \%$ hydrogen peroxide in $10 \mathrm{~mL}$ of water and $10 \mathrm{~mL}$ of methanol overnight at room temperature. The product was recovered magnetically, washed three times with $20 \mathrm{~mL}$ of water, and reacidified with $10 \mathrm{~mL}$ of $1 \mathrm{M} \mathrm{H}_{2} \mathrm{SO}_{4}$. The sulfonic acid-modified SBA-15 (SBA-15-SO ${ }_{3} \mathrm{H}$ ) were washed three times with water and dried under vacuum at room temperature overnight.

Synthesis of ionic liquid supported SBA-15. Supported imidazole ionic liquid catalyst was synthesized by the reaction of 1-methylimidazole and acid-modified SBA-15, by a procedure similar to Yarie et al. reported method. ${ }^{32}$ To do this, 1-methylimidazole $(100 \mathrm{mg}, 1.2 \mathrm{mmol})$ and acid-modified SBA-15 $(250 \mathrm{mg})$ were mixed together in a round bottom flask containing $50 \mathrm{~mL}$ of toluene and stirred at $80^{\circ} \mathrm{C}$ for $72 \mathrm{~h}$. After that time, the reaction mixture was washed by diethyl ether $(3 \times 10 \mathrm{~mL})$ to remove the unreacted compounds. The product was obtained as a white solid after drying under vacuum for $12 \mathrm{~h}$.

General procedure for the preparation of 2,3-dihydroquinazoline-4(1H)-ones (4a-d) and dihydroisoindolo[2,1-a]quinazoline-5,11-diones (6a-j). A solution of isatoic anhydride (1 mmol), amines (1 mmol), aldehydes (1 mmol), and ImIL-Sul-SBA-15 (20 mol\%) in EtOH: $\mathrm{H}_{2} \mathrm{O}(1: 1,3 \mathrm{~mL})$ was stirred at $50{ }^{\circ} \mathrm{C}$. Upon completion of the reaction, monitored by TLC, the precipitate was separated by filtration. The precipitate is mixture of desired product and ImIL-Sul-SBA-15. The ImIL-Sul-SBA-15 was recovered by filtration with EtOH as precipitate. Then, the solvent of filtrate was evaporated to give crude product which was then purified by recrystallization from EtOH: $\mathrm{H}_{2} \mathrm{O}(1: 1)$.

4.5.1 3-Benzyl-2-(4-chlorophenyl)-2,3-dihydroquinazolin-4(1H)-one (4a). White solid; mp 175-177 ${ }^{\circ} \mathrm{C}$ (Ref. ${ }^{33}$ $\left.122-124^{\circ} \mathrm{C}\right) . \mathrm{IR}(\mathrm{KBr}): \bar{v} 3279,1635,1518,1310,1295 \mathrm{~cm}^{-1} ;{ }^{1} \mathrm{H}$ NMR $\left(\mathrm{CDCl}_{3}\right): \delta 3.68\left(1 \mathrm{H}, \mathrm{d},{ }^{2} \mathrm{~J} 15.6 \mathrm{~Hz}, \mathrm{CH}\right), 5.59$ $\left(1 \mathrm{H}, \mathrm{d},{ }^{2} \mathrm{~J} 15.6 \mathrm{~Hz}, \mathrm{CH}\right), 5.60(1 \mathrm{H}, \mathrm{s}, \mathrm{CH}), 6.53\left(1 \mathrm{H}, \mathrm{d},{ }^{3}\right.$ J $\left.8.0 \mathrm{~Hz}, \mathrm{H}-\mathrm{Ar}\right), 6.88\left(1 \mathrm{H}, \mathrm{t},{ }^{3} \mathrm{~J} 7.6 \mathrm{~Hz}, \mathrm{H}-\mathrm{Ar}\right), 7.21-7.30(10 \mathrm{H}$,

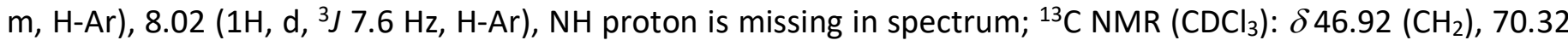
(CH), 114.44, 115.63, 119.40, 126.6, 127.53, 127.92, 128.65, 128.76, 129.09, 133.76, 135.11, 136.47, 137.85, 144.83 (18C, 3Ar), 163.11 (C=0) ppm.

4.5.2 3-benzyl-2-(4-methoxy)-2,3-dihydroquinazolin-4(1H)-one (4b). White solid; mp $119-121{ }^{\circ} \mathrm{C} . \mathrm{IR}(\mathrm{KBr}): \bar{v}$ $3358,3296,1633,1610,1307,1257 \mathrm{~cm}^{-1} ;{ }^{1} \mathrm{H} \mathrm{NMR}\left(\mathrm{CDCl}_{3}\right): \delta=3.66\left(1 \mathrm{H}, \mathrm{d},{ }^{2} \mathrm{~J} 15.4 \mathrm{~Hz}, \mathrm{CH}\right), 3.80\left(3 \mathrm{H}, \mathrm{s}, \mathrm{OCH}_{3}\right)$, $4.60(1 \mathrm{H}, \mathrm{br} s, \mathrm{NH}), 5.55\left(1 \mathrm{H}, \mathrm{d},{ }^{2} \mathrm{~J} 15.4 \mathrm{~Hz}, \mathrm{CH}\right), 5.60(1 \mathrm{H}, \mathrm{s}, \mathrm{CH}), 6.52\left(1 \mathrm{H}, \mathrm{d},{ }^{3} \mathrm{~J} 8.0 \mathrm{~Hz}, \mathrm{H}-\mathrm{Ar}\right), 6.83\left(2 \mathrm{H}, \mathrm{d},{ }^{3} \mathrm{~J} 8.6\right.$ $\mathrm{Hz}, \mathrm{H}-\mathrm{Ar}), 6.86-7.36(9 \mathrm{H}, \mathrm{m}, \mathrm{H}-\mathrm{Ar}), 8.03\left(1 \mathrm{H}, \mathrm{d},{ }^{3} \mathrm{~J} 7.7 \mathrm{~Hz}, \mathrm{H}-\mathrm{Ar}\right) ;{ }^{13} \mathrm{C} \mathrm{NMR}\left(\mathrm{CDCl}_{3}\right): \delta=46.69\left(\mathrm{CH}_{2}\right), 70.79(\mathrm{CH})$, $114.15,115.67,119.14,127.32,127.81,127.95,128.04,128.52,128.79,131.29,132.46,136.84,137.90$, 145.23 (18C, 3Ar), 163.27 (C=O) ppm. El-MS: $m / z$ (\%) = 344 (24), 253 (100), 237 (96), 210 (26), 91 (93), 77 (9). Anal. Calcd for $\mathrm{C}_{22} \mathrm{H}_{20} \mathrm{~N}_{2} \mathrm{O}_{2}$ (344.41): $\mathrm{C}, 76.72 \%$; $\mathrm{H}, 5.85 \%$; N, 8.13\%; found: $\mathrm{C}, 76.39 \%$; $\mathrm{H}, 5.61 \%$;, $7.86 \%$.

4.5.3 3-benzyl-2-(2,3-dichlorophenyl)-2,3-dihydroquinazolin-4(1H)-one (4c). White solid; $\mathrm{mp} 209-211{ }^{\circ} \mathrm{C}$ (Ref. $\left.{ }^{34} 206-208{ }^{\circ} \mathrm{C}\right) . \mathrm{IR}(\mathrm{KBr}): \bar{v} 3277,1628,1235,1171 \mathrm{~cm}^{-1} ;{ }^{1} \mathrm{H} \mathrm{NMR}\left(\mathrm{CDCl}_{3}\right): \delta 3.64\left(1 \mathrm{H}, \mathrm{d},{ }^{2} \mathrm{~J} 15.2 \mathrm{~Hz}, \mathrm{CH}\right)$, $5.00(1 \mathrm{H}, \mathrm{br} \mathrm{s}, \mathrm{NH}), 5.71\left(1 \mathrm{H}, \mathrm{d},{ }^{2} \mathrm{~J} 15.2 \mathrm{~Hz}, \mathrm{CH}\right), 6.00(1 \mathrm{H}, \mathrm{s}, \mathrm{CH}), 6.49\left(1 \mathrm{H}, \mathrm{d},{ }^{3} \mathrm{~J} 8.0 \mathrm{~Hz}, \mathrm{H}-\mathrm{Ar}\right), 6.85\left(1 \mathrm{H}, \mathrm{t},{ }^{3} \mathrm{~J} 7.6\right.$

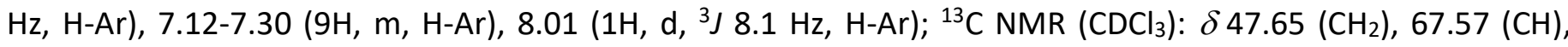
$114.66,115.45,119.45,125.28,127.78,127.79,128.07,128.67,128.77,130.21,130.78,133.83,134.08$, $136.20,138.38,144.15$ (18C, 3Ar), 163.42 (C=0) ppm.

4.5.4 3-Allyl-2-(4-chlorophenyl)-2,3-dihydroquinazolin-4(1H)-one (4d). White solid; $\mathrm{mp} 168-170{ }^{\circ} \mathrm{C}$. IR $(\mathrm{KBr}): \bar{v}=3298,1631,1510,1306,1235 \mathrm{~cm}^{-1} ;{ }^{1} \mathrm{H} \mathrm{NMR}\left(\mathrm{CDCl}_{3}\right): \delta=3.23\left(1 \mathrm{H}, \mathrm{dd},{ }^{2} \mathrm{~J} 15.7 \mathrm{~Hz},{ }^{3} \mathrm{~J} 7.4 \mathrm{~Hz}, \mathrm{CH}\right), 4.84$ $\left(1 \mathrm{H}, \mathrm{dd},{ }^{2} \mathrm{~J} 15.7 \mathrm{~Hz},{ }^{3} \mathrm{~J} 7.4 \mathrm{~Hz}, \mathrm{CH}\right), 5.17\left(1 \mathrm{H}, \mathrm{d},{ }^{3} \mathrm{~J}_{\text {cis }} 10.7 \mathrm{~Hz},=\mathrm{CH}\right), 5.20\left(1 \mathrm{H}, \mathrm{d},{ }^{3} J_{\text {trans }} 17.5 \mathrm{~Hz},=\mathrm{CH}\right), 5.73(1 \mathrm{H}, \mathrm{s}$, $\mathrm{CH}), 5.79(1 \mathrm{H}, \mathrm{m},=\mathrm{CH}), 6.54\left(1 \mathrm{H}, \mathrm{d},{ }^{3} \mathrm{~J} 8.1 \mathrm{~Hz}, \mathrm{H}-\mathrm{Ar}\right), 6.87\left(1 \mathrm{H}, \mathrm{t},{ }^{3} \mathrm{~J} 7.6 \mathrm{~Hz}, \mathrm{H}-\mathrm{Ar}\right), 7.31(5 \mathrm{H}, \mathrm{m}, \mathrm{H}-\mathrm{Ar}), 7.97(1 \mathrm{H}, \mathrm{d}$, 3) $7.5 \mathrm{~Hz}, \mathrm{H}-\mathrm{Ar}), \mathrm{NH}$ proton is missing in spectrum; ${ }^{13} \mathrm{C} \mathrm{NMR}\left(\mathrm{CDCl}_{3}\right): \delta=46.25\left(\mathrm{CH}_{2}\right), 70.51(\mathrm{CH}), 114.40$, 
115.89, $117.92\left(=\mathrm{CH}_{2}\right), 119.51,127.95,128.65,129.14,132.43(=\mathrm{CH}), 133.66,135.16,137.97,144.76(12 \mathrm{C}$, 2Ar), $162.76(\mathrm{C}=0)$ ppm. El-MS: $m / z(\%)=300\left(\mathrm{M}^{++}+2,7\right), 298\left(\mathrm{M}^{+}, 11\right), 257(22), 187(100), 147(24), 119(15)$, 92 (11). Anal. Calcd for $\mathrm{C}_{17} \mathrm{H}_{15} \mathrm{ClN}_{2} \mathrm{O}$ (298.77): $\mathrm{C}, 68.34 \% ; \mathrm{H}, 5.06 \% ; \mathrm{N}, 9.38 \%$; found: $\mathrm{C}, 68.61 \% ; \mathrm{H}, 4.82 \%$; , $9.02 \%$.

4.5.5 6-Benzyl-6,6a-dihydroisoindolo[2,1-a]quinazoline-5,11-dione (6a). White solid; mp 140-142 ${ }^{\circ} \mathrm{C}$ (Ref. ${ }^{35}$ 148-150 $\left.{ }^{\circ} \mathrm{C}\right) . \mathrm{IR}(\mathrm{KBr}): \bar{v} 3028,1721,1654,1601,1486,1465 \mathrm{~cm}^{-1} ;{ }^{1} \mathrm{H} \mathrm{NMR}\left(\mathrm{CDCl}_{3}\right): \delta=4.62\left(1 \mathrm{H}, \mathrm{d},{ }^{2} J 16.7 \mathrm{~Hz}\right.$, $\mathrm{CH}), 5.53\left(1 \mathrm{H}, \mathrm{d},{ }^{2} \mathrm{~J} 16.7 \mathrm{~Hz}, \mathrm{CH}\right), 6.37(1 \mathrm{H}, \mathrm{s}, \mathrm{CH}), 7.21-8.24(13 \mathrm{H}, \mathrm{m}, \mathrm{H}-\mathrm{Ar}) ;{ }^{13} \mathrm{C} \mathrm{NMR}\left(\mathrm{CDCl}_{3}\right): \delta 46.61\left(\mathrm{CH}_{2}\right)$, 70.65 (CH), 120.19, 120.29, 124.97, 125.31, 125.40, 126.25, 127.25, 129.03, 129.46, 130.59, 132.52, 132.68, $133.71,136.14,136.89,137.69$ (18C, 3Ar), 164.08, 164.84 (2C=0) ppm.

4.5.6 6-Allyl-6,6a-dihydroisoindolo[2,1-a] quinazoline-5,11-dione (6b). White solid; mp 124-126 ${ }^{\circ} \mathrm{C}$. IR (KBr): $\bar{v}$ $3084,2930,1713,1648,1488,1469 \mathrm{~cm}^{-1}$; ${ }^{1} \mathrm{H}$ NMR $\left(\mathrm{CDCl}_{3}\right): \delta=4.09\left(1 \mathrm{H}, \mathrm{dd},{ }^{2} \mathrm{~J} 16.6 \mathrm{~Hz},{ }^{3} \mathrm{~J} 4.6 \mathrm{~Hz}, \mathrm{CH}\right), 4.81(1 \mathrm{H}$, d, $\left.{ }^{2} J 16.6 \mathrm{~Hz}, \mathrm{CH}\right), 5.22\left(1 \mathrm{H}, \mathrm{d},{ }^{3} J_{\text {trans }} 19.6 \mathrm{~Hz},=\mathrm{CH}\right), 5.27\left(1 \mathrm{H}, \mathrm{d},{ }^{3}{ }_{\text {cis }} 11.8 \mathrm{~Hz},=\mathrm{CH}\right), 5.91(1 \mathrm{H}, \mathrm{m},=\mathrm{CH}), 6.32(1 \mathrm{H}, \mathrm{s}$, $\mathrm{CH}), \quad 7.33-8.17(8 \mathrm{H}, \mathrm{m}, \mathrm{H}-\mathrm{Ar}) ;{ }^{13} \mathrm{C} \mathrm{NMR}\left(\mathrm{CDCl}_{3}\right): \delta 45.10\left(\mathrm{CH}_{2}\right), 70.47(\mathrm{CH}), 116.79\left(=\mathrm{CH}_{2}\right), 120.06,120.18$, 125.04, 125.25, 129.24, 130.63, 132.63 (=CH), 132.71, 132.80, 133.58, 136.79, 137.86 (12C, 2Ar), 163.65, 164.74 (2C=O) ppm. El-MS: m/z (\%) = 290 (100), 261 (45), 233 (50), 218 (18), 116 (13), 89 (18), 63 (14). Anal. Calcd for $\mathrm{C}_{18} \mathrm{H}_{14} \mathrm{~N}_{2} \mathrm{O}_{2}$ (290.32): C, 74.47\%; $\mathrm{H}, 4.86 \%$; N, 9.65\%; found: $\mathrm{C}, 74.11 \% ; \mathrm{H}, 5.18 \% ; \mathrm{N}, 9.37 \%$.

4.5.7 6-(2-Chlorobenzyl)-6,6a-dihydroisoindolo[2,1-a]quinazoline-5,11-dione (6c). White solid; mp 180-182 ${ }^{\circ} \mathrm{C}$ (Ref. $\left.{ }^{36} 185-188^{\circ} \mathrm{C}\right) . \mathrm{IR}(\mathrm{KBr}): \bar{v} 1708,1687,1601,1491 \mathrm{~cm}^{-1} ;{ }^{1} \mathrm{H}$ NMR $\left(\mathrm{CDCl}_{3}\right): \delta 5.04\left(1 \mathrm{H}, \mathrm{d},{ }^{2} \mathrm{~J} 17.5 \mathrm{~Hz}, \mathrm{CH}\right)$, $5.27\left(1 \mathrm{H}, \mathrm{d},{ }^{2} \mathrm{~J} 17.5 \mathrm{~Hz}, \mathrm{CH}\right), 6.37(1 \mathrm{H}, \mathrm{s}, \mathrm{CH}), 7.05-8.23(12 \mathrm{H}, \mathrm{m}, \mathrm{H}-\mathrm{Ar}) ;{ }^{13} \mathrm{C} \mathrm{NMR}\left(\mathrm{CDCl}_{3}\right): \delta 44.72\left(\mathrm{CH}_{2}\right), 70.66$ (CH), 120.0, 120.3, 124.8, 124.9, 125.4, 126.8, 127.2, 128.4, 129.5, 129.8, 130.6, 132.1, 132.4, 132.7, 133.6, $133.9,137.0,137.4$ (18C, 3Ar), 164.17, $164.92(2 \mathrm{C}=0) \mathrm{ppm}$.

4.5.8 6-(Furan-2-ylmethyl)-6,6a-dihydroisoindolo[2,1-a]quinazoline-5,11-dione (6d). White solid; mp 173-175 ${ }^{\circ} \mathrm{C}$ (Ref. $\left.{ }^{37} 175-176{ }^{\circ} \mathrm{C}\right)$. IR (KBr): $\bar{v} 1722,1668,1602,1489 \mathrm{~cm}^{-1} ;{ }^{1} \mathrm{H}$ NMR (DMSO-d $): \delta 4.77\left(1 \mathrm{H}, \mathrm{d},{ }^{2} \mathrm{~J} 16.8 \mathrm{~Hz}\right.$, $\mathrm{CH}), 5.12\left(1 \mathrm{H}, \mathrm{d},{ }^{2} \mathrm{~J} 16.8 \mathrm{~Hz}, \mathrm{CH}\right), 6.15\left(1 \mathrm{H}, \mathrm{d}, 3\right.$ J $\left.3.0 \mathrm{~Hz},=\mathrm{CH}_{\text {furan }}\right), 6.33\left(1 \mathrm{H}, \mathrm{t}, 3 \mathrm{~J} 3.0 \mathrm{~Hz},=\mathrm{CH}_{\text {furan }}\right), 6.63(1 \mathrm{H}, \mathrm{s}, \mathrm{CH})$, $7.40(1 \mathrm{H}, \mathrm{t}, 3$ J $7.5 \mathrm{~Hz}, \mathrm{H}-\mathrm{Ar}), 7.53\left(1 \mathrm{H}, \mathrm{t},{ }^{3}\right.$ J $\left.3.0 \mathrm{~Hz},=\mathrm{CH}_{\text {furan }}\right), 7.70-7.93(5 \mathrm{H}, \mathrm{m}, \mathrm{H}-\mathrm{Ar}), 8.03\left(2 \mathrm{H}, \mathrm{d},{ }^{3} \mathrm{~J} 8.1 \mathrm{~Hz}, \mathrm{H}-\mathrm{Ar}\right)$; ${ }^{13} \mathrm{C}$ NMR (DMSO-d $\left.d_{6}\right): \delta 45.00\left(\mathrm{CH}_{2}\right), 70.20(\mathrm{CH}), 107.38\left(\mathrm{C}_{4^{\prime}}\right), 110.53\left(\mathrm{C}_{3^{\prime}}\right), 119.87,119.93,121.42,124.23$, $125.06,126.07,128.59,130.65,133.08,133.57,136.63,138.10$ (12C, $2 A r), 142.33\left(C_{5^{\prime}}\right), 150.41\left(C_{2^{\prime}}\right), 162.98$, $164.30(2 \mathrm{C}=0) \mathrm{ppm}$.

4.5.9 6,6a-Dihydro-6-(pyridin-2-ylmethyl)isoindolo[2,1-a]quinazoline-5,11-dione (6e). White solid; mp 215$217^{\circ} \mathrm{C}$ (Ref. ${ }^{36} 212-214{ }^{\circ} \mathrm{C}$ ). IR (KBr): $\bar{v} 1722,1660,1597 \mathrm{~cm}^{-1} ;{ }^{1} \mathrm{H}$ NMR (DMSO-d $\left.d_{6}\right): \delta 4.90\left(1 \mathrm{H}, \mathrm{d},{ }^{2} J 17.3 \mathrm{~Hz}, \mathrm{CH}\right.$ ), $5.26\left(1 \mathrm{H}, \mathrm{d},{ }^{2} \mathrm{~J} 17.3 \mathrm{~Hz}, \mathrm{CH}\right), 6.81(1 \mathrm{H}, \mathrm{s}, \mathrm{CH}), 7.23-8.48(12 \mathrm{H}, \mathrm{m}, \mathrm{H}-\mathrm{Ar}),{ }^{13} \mathrm{C}$ NMR (DMSO-d $): \delta 47.48\left(\mathrm{CH}_{2}\right), 70.65$ (CH), 119.88, 119.93, 121.20, 122.19, 124.13, 125.01, 125.89, 128.60, 130.49, 131.91, 132.86, 133.52, 136.79, $136.88,138.10,149.05,156.70$ (17C, 2Ar and pyridine), 163.29, 164.31 (2C=0) ppm.

4.5.10 6-(4-Chlorobenzyl)-6,6a-dihydroisoindolo[2,1-a]quinazoline-5,11-dione (6f). White solid; mp 174-176 ${ }^{\circ} \mathrm{C}$ (Ref. $\left.{ }^{35} 178-181^{\circ} \mathrm{C}\right) . \mathrm{IR}(\mathrm{KBr}): \bar{v} 1718,1662,1605,1492 \mathrm{~cm}^{-1} ;{ }^{1} \mathrm{H}$ NMR (DMSO-d $): \delta 5.02\left(1 \mathrm{H}, \mathrm{d},{ }^{2} \mathrm{~J} 17.2 \mathrm{~Hz}\right.$, $\mathrm{CH}), 5.09\left(1 \mathrm{H}, \mathrm{d},{ }^{2}\right.$ J $\left.17.2 \mathrm{~Hz}, \mathrm{CH}\right), 6.71(1 \mathrm{H}, \mathrm{s}, \mathrm{CH}), 7.08(2 \mathrm{H}, \mathrm{d}, 3 \mathrm{3} 8.4 \mathrm{~Hz}, \mathrm{H}-\mathrm{Ar}), 7.24(2 \mathrm{H}, \mathrm{t}, 3 \mathrm{~s} 8.4 \mathrm{~Hz}, \mathrm{H}-\mathrm{Ar}), 7.42$ $\left(1 \mathrm{H}, \mathrm{t},{ }^{3} \mathrm{~J} 7.7 \mathrm{~Hz}, \mathrm{H}-\mathrm{Ar}\right), 7.60-7.86(5 \mathrm{H}, \mathrm{m}, \mathrm{H}-\mathrm{Ar}), 8.05\left(2 \mathrm{H}, \mathrm{d},{ }^{3} \mathrm{~J} 8.7, \mathrm{H}-\mathrm{Ar}\right) ;{ }^{13} \mathrm{C}$ NMR (DMSO-d 6 ): $\delta 45.09\left(\mathrm{CH}_{2}\right)$, $70.21(\mathrm{CH}), 119.96,124.09,125.10,126.08,127.83,128.25,128.62,130.53,131.08,131.68,132.91,133.51$, $136.51,136.66,137.91$ (18C, 3Ar), 163.33, 164.29 (2C=0) ppm.

4.5.11 6-Benzyl-6,6a-dihydro-9,10-dimethoxyisoindolo[2,1-a]quinazoline-5,11-dione (6g). White solid; $\mathrm{mp}$ 206-208 ${ }^{\circ} \mathrm{C}$ (Ref. ${ }^{36} 197-200{ }^{\circ} \mathrm{C}$ ). IR (KBr): $\bar{v} 1710,1656,1602,1492 \mathrm{~cm}^{-1} ;{ }^{1} \mathrm{H}$ NMR (DMSO-d $\left.d_{6}\right): \delta 3.81(3 \mathrm{H}, \mathrm{s}$, $\left.\mathrm{OCH}_{3}\right), 3.86\left(3 \mathrm{H}, \mathrm{s}, \mathrm{OCH}_{3}\right), 4.90\left(1 \mathrm{H}, \mathrm{d},{ }^{2} \mathrm{~J} 16.9 \mathrm{~Hz}, \mathrm{CH}\right), 5.06\left(1 \mathrm{H}, \mathrm{d},{ }^{2} J 16.9 \mathrm{~Hz}, \mathrm{CH}\right), 6.54(1 \mathrm{H}, \mathrm{s}, \mathrm{CH}), 7.07(2 \mathrm{H}, \mathrm{d}$, 3ر $7.7 \mathrm{~Hz}, \mathrm{H}-\mathrm{Ar}), 7.16(1 \mathrm{H}, \mathrm{t}, 3$ J $7.1 \mathrm{~Hz}, \mathrm{H}-\mathrm{Ar}), 7.23-7.30(6 \mathrm{H}, \mathrm{m}, \mathrm{H}-\mathrm{Ar}), 8.00(1 \mathrm{H}, \mathrm{d}, 3 \mathrm{~J}$ 8.2, H-Ar), $8.04(1 \mathrm{H}, \mathrm{d}, 3 \mathrm{~J}$ 7.8, H-Ar); ${ }^{13} \mathrm{C}$ NMR (DMSO- $\left.d_{6}\right): \delta 45.54\left(\mathrm{CH}_{2}\right), 56.33,61.70\left(2 \mathrm{OCH}_{3}\right), 69.07(\mathrm{CH}), 117.27,120.14,120.21$, 
$121.54,123.77,124.98,125.97,126.59,128.40,128.59,130.25,133.30,136.76,137.29,146.94,153.66$ (18C, $3 \mathrm{Ar}), 162.46,163.16(2 \mathrm{C}=0) \mathrm{ppm}$.

4.6.12 6-(Furan-2-ylmethyl)-6,6a-dihydro-9,10-dimethoxyisoindolo[2,1-a]quinazoline-5,11-dione (6h). White solid; mp 179-181 ${ }^{\circ} \mathrm{C}$ (Ref. ${ }^{36} 181-183^{\circ} \mathrm{C}$ ). IR (KBr): $\bar{v} 1731,1660,1601 \mathrm{~cm}^{-1} ;{ }^{1} \mathrm{H}$ NMR (DMSO- $\left.d_{6}\right): \delta 3.88(3 \mathrm{H}, \mathrm{s}$, $\left.\mathrm{OCH}_{3}\right), 3.91\left(3 \mathrm{H}, \mathrm{s}, \mathrm{OCH}_{3}\right), 4.66\left(1 \mathrm{H}, \mathrm{d},{ }^{2} \mathrm{~J} 16.8 \mathrm{~Hz}, \mathrm{CH}\right), 5.08\left(1 \mathrm{H}, \mathrm{d},{ }^{2}\right.$ J $\left.16.8 \mathrm{~Hz}, \mathrm{CH}\right), 6.17(1 \mathrm{H}, \mathrm{d}, 3] 3.0 \mathrm{~Hz}$, $\left.=\mathrm{CH}_{\text {furan }}\right), 6.36\left(1 \mathrm{H}, \mathrm{dd},{ }^{3} \mathrm{~J} 3.0,1.9 \mathrm{~Hz},=\mathrm{CH}_{\text {furan }}\right), 6.46(1 \mathrm{H}, \mathrm{s}, \mathrm{CH}), 7.37(1 \mathrm{H}, \mathrm{t}, 3 \mathrm{~J} 7.3 \mathrm{~Hz}, \mathrm{H}-\mathrm{Ar}), 7.43\left(1 \mathrm{H}, \mathrm{d}, 3^{3} \mathrm{~J} 8.4\right.$ $\mathrm{Hz}, \mathrm{H}-\mathrm{Ar}), 7.49\left(1 \mathrm{H}, \mathrm{d},{ }^{3} \mathrm{~J} 8.4 \mathrm{~Hz}, \mathrm{H}-\mathrm{Ar}\right), 7.56\left(1 \mathrm{H}, \mathrm{d},{ }^{3} \mathrm{~J} 1.9 \mathrm{~Hz},=\mathrm{CH}_{\text {furan }}\right), 7.69-8.00(3 \mathrm{H}, \mathrm{m}, \mathrm{H}-\mathrm{Ar}) ;{ }^{13} \mathrm{C} \mathrm{NMR}$ (DMSO-d $\left.d_{6}\right): \delta 47.20\left(\mathrm{CH}_{2}\right), 56.37,61.74\left(2 \mathrm{CCH}_{3}\right), 69.06(\mathrm{CH}), 107.32\left(\mathrm{C}_{4^{\prime}}\right), 110.57\left(\mathrm{C}_{3^{\prime}}\right), 117.40,120.02,120.18$, 121.59, 123.81, 124.95, 128.51, 130.31, 133.37, 136.72, 147.08, 153.81 (12C, 2Ar), $142.32\left(C_{5^{\prime}}\right), 150.48\left(C_{2^{\prime}}\right)$, $162.47,162.91(2 \mathrm{C}=0) \mathrm{ppm}$.

4.5.13 6,6a-Dihydro-9,10-dimethoxy-6-(pyridin-2-ylmethyl)isoindolo[2,1-a]quinazoline-5,11-dione (6i). White solid; mp 214-216 ${ }^{\circ} \mathrm{C}$ (Ref. ${ }^{36} 210-212{ }^{\circ} \mathrm{C}$ ). IR (KBr): $\bar{v} 1726,1659,1603,1590 \mathrm{~cm}^{-1} ;{ }^{1} \mathrm{H}$ NMR (DMSO- $d_{6}$ ): $\delta$ $3.82\left(3 \mathrm{H}, \mathrm{s}, \mathrm{OCH}_{3}\right), 3.90\left(3 \mathrm{H}, \mathrm{s}, \mathrm{OCH}_{3}\right), 4.83\left(1 \mathrm{H}, \mathrm{d},{ }^{2} \mathrm{~J} 17.2 \mathrm{~Hz}, \mathrm{CH}\right), 5.22\left(1 \mathrm{H}, \mathrm{d},{ }^{2} \mathrm{~J} 17.2 \mathrm{~Hz}, \mathrm{CH}\right), 6.64(1 \mathrm{H}, \mathrm{s}, \mathrm{CH})$, 7.12-8.50 (10H, m, H-Ar); ${ }^{13} \mathrm{C}$ NMR (DMSO- $\left.d_{6}\right): \delta 47.24\left(\mathrm{CH}_{2}\right), 56.33,61.72\left(2 \mathrm{OCH}_{3}\right), 69.49(\mathrm{CH}), 117.24,120.14$, $121.29,121.43,122.21,123.92,124.91,128.52,130.35,133.35,136.88,136.99,146.98,148.96,153.69$, 156.74 (17C, 2 Ar and pyridine), 162.49, 163.23 (2C=0) ppm.

4.5.14 6-(4-Chlorobenzyl)-6,6a-dihydro-9,10-dimethoxyisoindolo[2,1-a]quinazoline-5,11-dione (6j). White solid; mp 185-187 ${ }^{\circ} \mathrm{C}$ (Ref. ${ }^{36} 180-182{ }^{\circ} \mathrm{C}$ ). IR (KBr): $\bar{v} 1726,1658,1606,1491 \mathrm{~cm}^{-1} ;{ }^{1} \mathrm{H}$ NMR (DMSO- $\left.d_{6}\right): \delta 3.82$ $\left(3 \mathrm{H}, \mathrm{s}, \mathrm{OCH}_{3}\right), 3.87\left(3 \mathrm{H}, \mathrm{s}, \mathrm{OCH}_{3}\right), 4.97\left(2 \mathrm{H}, \mathrm{br} \mathrm{s}, \mathrm{CH}_{2}\right), 6.53(1 \mathrm{H}, \mathrm{s}, \mathrm{CH}), 7.08(2 \mathrm{H}, \mathrm{d}, 3 \mathrm{~s} 7.7 \mathrm{~Hz}, \mathrm{H}-\mathrm{Ar}), 7.26-8.04$ $(8 \mathrm{H}, \mathrm{m}, \mathrm{H}-\mathrm{Ar}) ;{ }^{13} \mathrm{C}$ NMR (DMSO- $\left.d_{6}\right): \delta 45.00\left(\mathrm{CH}_{2}\right), 56.35,61.70(2 \mathrm{OCH}), 69.07(\mathrm{CH}), 117.32,120.16,120.21$, $121.62,123.72,124.98,127.92,128.27,128.57,130.20,131.10,133.32,136.56,136.77,146.97,153.69$ (18C, $3 \mathrm{Ar}), 162.44,163.25(2 \mathrm{C}=0) \mathrm{ppm}$.

\section{Supplementary Material}

Copies of ${ }^{1} \mathrm{H},{ }^{13} \mathrm{C}$ NMR and some Mass spectra of compounds $\mathbf{4 a - d}$ and $\mathbf{6 a - j}$ are provided in the supplementary material file available on the Publisher's web site.

\section{References}

1. Deutschmann, O.; Knözinger, H.; Kochloefl, K. Turek, Ullmann's Encyclopedia of Industrial Chemistry, Weinheim, 2009.

http://dx.doi.org/10.1002/14356007.a05 313.pub2

2. Sharma, Y. C.; Singh, B.; Korstad, J. Biofuels, Bioproducts Biorefining 2011, 5, 69-92. http://dx.doi.org/10.1002/bbb.253

3. Zolfigol, M. A.; Ayazi-Nasrabadi, R.; Baghery, S. RSC Adv. 2015, 5, 71942-71954. http://dx.doi.org/10.1039/C5RA14001C

4. Andrei, R. D.; Popa, M. I.; Fajula, F.; Hulea, V. J. Catal. 2015, 323, 76-84. http://dx.doi.org/10.1016/i.jcat.2014.12.027

5. Jeon, M.-J.; Jeon, J.-K.; Suh, D. J.; Park, S. H.; Sa, Y. J.; Joo, S. H.; Park, Y.-K. Catalysis Today 2013, 204, 170178.

http://dx.doi.org/10.1016/i.cattod.2012.07.039

6. Pal, N.; Bhaumik, A. RSC Adv. 2015, 5, 24363-24391.

http://dx.doi.org/10.1039/C4RA13077D 
7. Wang, Z.; Wang, M.; Yao, X.; Li, Y.; Tan, J.; Wang, L.; Qiao, W.; Geng, Y.; Liu, Y.; Wang, Q. Eur. J. Med. Chem. 2012, 53, 275-282.

http://dx.doi.org/10.1016/i.ejmech.2012.04.010

8. Ozaki, K.-I.; Yamada, Y.; Oine, T.; Ishizuka, T.; Iwasawa, Y. J. Med. Chem. 1985, 28, 568-576. http://dx.doi.org/10.1021/im50001a006

9. Abbas, S. E.; Awadallah, F. M.; Ibrahin, N. A.; Said, E. G.; Kamel, G. M. Eur. J. Med. Chem. 2012, 53, 141-149. http://dx.doi.org/10.1016/i.ejmech.2012.03.050

10. Smits, R. A.; de Esch, I. J.; Zuiderveld, O. P.; Broeker, J.; Sansuk, K.; Guaita, E.; Coruzzi, G.; Adami, M.; Haaksma, E.; Leurs, R. J. Med. Chem. 2008, 51, 7855-7865. http://dx.doi.org/10.1021/im800876b

11. Chinigo, G. M.; Paige, M.; Grindrod, S.; Hamel, E.; Dakshanamurthy, S.; Chruszcz, M.; Minor, W.; Brown, M. L. J. Med. Chem. 2008, 51, 4620-4631. http://dx.doi.org/10.1021/jm800271c

12. Alaimo, R. J.; Russel, H. E. J. Med. Chem. 1972, 15, 335-336. http://dx.doi.org/10.1021/jm00273a034

13. Saravanan, G.; Alagarsamy, V.; Prakash, C. R. Bioorg. Med. Chem. Lett. 2012, 22, 3072-3078. http://dx.doi.org/10.1016/i.bmcl.2012.03.068

14. Rueping, M.; Antonchick, A. P.; Sugiono, E.; Grenader, K. Angew. Chem. Int. Ed. 2009, 48, 908-910. http://dx.doi.org/10.1002/anie.200804770

15. Bonola, G.; Da Re, P.; Magistretti, M. J.; Massarani, E.; Setnikar, I. J. Med. Chem. 1968, 11, 1136-1139. http://dx.doi.org/10.1021/im00312a007

16. Rhee, H.-K.; Yoo, J. H.; Lee, E.; Kwon, Y. J.; Seo, H.-R.; Lee, Y.-S.; Choo, H.-Y. P. Eur. J. Med. Chem. 2011, 46, 3900-3908. http://dx.doi.org/10.1016/i.ejmech.2011.05.061

17. Salehi, P.; Dabiri, M.; Baghbanzadeh, M.; Bahramnejad, M. Synth. Commun. 2006, 36, 2287-2292. http://dx.doi.org/10.1080/00397910600639752

18. Chen, J.; Wu, D.; He, F.; Liu, M.; Wu, H.; Ding, J.; Su, W. Tetrahedron Lett. 2008, 49, 3814-3818. http://dx.doi.org/10.1016/i.tetlet.2008.03.127

19. Dabiri, M.; Salehi, P.; Baghbanzadeh, M. Monatsh. Chem. 2007, 138, 1191-1194. http://dx.doi.org/10.1007/s00706-007-0635-0

20. Rostamizadeh, S.; Amani, A. M.; Mahdavinia, G. H.; Sepehrian, H.; Ebrahimi, S. Synthesis 2010, 8, 13561360.

http://dx.doi.org/10.1055/s-0029-1218676

21. Kassaee, M. Z.; Rostamizadeh, S.; Shadjou, N.; Motamedi, E.; Esmaeelzadeh, M. J. Heterocyclic Chem. 2010, 47, 1421-1424.

http://dx.doi.org/10.1002/jhet.506

22. Rao, A. D.; Vykunteswararao, B. P.; Bhaskarkumar, T.; Jogdand, N. R.; Kalita, D.; Lilakar, J. K. D.; Siddaiah, V.; Sanasi, P. D.; Raghunadh, A. Tetrahedron Lett. 2015, 56, 4714-4717. http://dx.doi.org/10.1016/i.tetlet.2015.06.004

23. Dabiri, M.; Salehi, P.; Baghbanzadeh, M.; Zolfigol, M. A.; Agheb, M.; Heydari, S. Catal. Commun. 2008, 9, 785-788.

http://dx.doi.org/10.1016/i.catcom.2007.08.019 
24. Dabiri, M.; Salehi, P.; Otokesh, S.; Baghbanzadeh, M.; Kozehgary, G.; Mohammadi, A. A. Tetrahedron Lett. 2005, 46, 6123-6126. http://dx.doi.org/10.1016/j.tetlet.2005.06.157

25. Sharma, M.; Pandey, S.; Chauhan, K.; Sharma, D.; Kumar, B.; Chauhan, P. M. J. Org. Chem. 2012, 77, 929937. http://dx.doi.org/10.1021/jo2020856

26. Wang, L.-M.; Hu, L.; Shao, J.-H.; Yu, J.; Zhang, L. J. Fluorine Chem. 2008, 129, 1139-1145. http://dx.doi.org/10.1016/i.jfluchem.2008.08.005

27. Rostamizadeh, S.; Amani, A. M.; Aryan, R.; Ghaieni, H. R.; Shadjou, N. Synth. Commun. 2008, 38, 35673576.

http://dx.doi.org/10.1080/00397910802178427

28. Salehi, P.; Dabiri, M.; Zolfigol, M. A.; Baghbanzadeh, M. Synlett 2005, 1155-1157. http://dx.doi.org/10.1055/s-2005-865200

29. Baghbanzadeh, M.; Salehi, P.; Dabiri, M.; Kozehgary, G. Synthesis 2006, 344-348. http://dx.doi.org/10.1055/s-2005-924766

30. Sashidhar, K. V.; Palnati, G. R.; Dodda, R. P.; Avula, S. R.; Swami, P. Synlett 2013, 24, 105-113. http://dx.doi.org/10.1055/s-0032-1317761

31. Mohammadi Ziarani, G.; Moradi, R.; Lashgari, N.; Badiei, A.; Abolhassani Soorki, A. Polycycl. Aromat. Compd. 2016, 1-9.

http://dx.doi.org/10.1080/10406638.2016.1154579

32. Yarie, M.; Zolfigol, M. A.; Bayat, Y.; Asgari, A.; Alonso, D. A.; Khoshnood, A. RSC Adv. 2016, 6, 82842-82853. http://dx.doi.org/10.1039/C6RA16459E

33. Yavari, I.; Beheshti, S. J. Iran. Chem. Soc. 2011, 8, 1030-1035. http://dx.doi.org/10.1007/BF03246559

34. Karimi-Jaberi, Z.; Arjmandi, R. Monatsh Chem. 2011, 142, 631-635. http://dx.doi.org/10.1007/s00706-011-0494-6

35. Kumar, K. S.; Kumar, P. M.; Kumar, K. A.; Sreenivasulu, M.; Jafar, A. A.; Rambabu, D.; Krishna, G. R.; Reddy, C. M.; Kapavarapu, R.; Shivakumar, K.; Priya, K. K.; Parsa, K. V. L.; Pal, M. Chem. Commun. 2011, 47, 50105012.

http://dx.doi.org/10.1039/C1CC10715A

36. Mahdavi, M.; Najafi, R.; Saeedi, M.; Alipour, E.; Shafiee, A.; Foroumadi, A. Helvetica Chimica Acta 2013, 96, 419-423.

http://dx.doi.org/10.1002/ hlca.201200199

37. Lu, L.; Yang, K.; Zhang, M.-M.; Wang, X.-S. J. Heterocyclic Chem. 2014, 51, 630-634. http://dx.doi.org/10.1002/jhet.1696 